\title{
Ventricular Outflow Tract Obstruction Secondary to Leiomyosarcoma of the Right Ventricle
}

\author{
Willem Willaert, ${ }^{1}$ MD, Philip Claessens, ${ }^{1}$ MD, Amir Shoja, ${ }^{1}$ MD, \\ Andre Heremans, ${ }^{1} \mathrm{MD}$, Herve DeFERM, ${ }^{1} \mathrm{MD}$, Jan RoElandTs, ${ }^{1} \mathrm{MD}$, \\ and Marc VANDERHEYDEN, ${ }^{1} \mathrm{MD}$
}

\begin{abstract}
SUMMARY
Primary leiomyosarcomas of the heart, particularly those affecting the right ventricle, are uncommon. We report the case of a 70-year-old Belgian woman presenting with the symptoms of progressive exertional dyspnea and left-sided pleuritic pain. A leiomyosarcoma which originated from the right lateral ventricle wall, causing pulmonary outflow obstruction. was diagnosed. Pathology revealed a neoplasm with a myxoid stroma, high mitotic activity and nuclei expressing atypia. Immunohistochemical staining was positive for vimentine and desmin. Seven months after complete surgical resection the tumor relapsed.

This case demonstrates the poor outcome, the high relapse rate and inefficiency of treatment associated with primary cardiac leiomyosarcomas. The current literature regarding the incidence, diagnostic techniques, treatment strategies and survival rates of this rare but terminal disease is reviewed. (Jpn Heart J 2001; 42: 377-386)
\end{abstract}

Key words: Cardiac neoplasm, Leiomyosarcoma, Right ventricle

PRIMARY cardiac tumors are uncommon. The majority of the neoplasms are benign $^{1)}$ and therefore curable when surgically treated. Leiomyosarcomas represent an extremely small minority of primary cardiac tumors ${ }^{2)}$ and are associated with an unfavourable outcome. They represent an infrequent cause of ventricular outflow obstruction.

Newer diagnostic techniques have led to earlier detection and have subsequently enhanced the potential for more effective management. Nonetheless the preferred treatment of surgical resection is considered palliative as metastasis and tumor relapse are frequent. Survival rates are poor and rarely exceed 1 year. ${ }^{3)}$

We report the case of a 70-year-old Belgian woman admitted with severe dyspnea and left-sided pleuritic pain. Diagnostic examination revealed a mass in the outflow tract of the right ventricle which, after surgical resection and histological examination, proved to be a leiomyosarcoma.

From ${ }^{1}$ Department of Cardiology, Imelda Ziekenhuis, Bonheiden, B-2820, Belgium.

Address for correspondence: Philip Claessens, MD, Rubenslei 35, 2018 Antwerp, Belgium.

Received for publication January 4, 2001.

Revised and accepted January 29, 2001. 


\section{Case Presentation}

Patient characteristics and physical examination: A 70-year-old woman was admitted to hospital because of progressive dyspnea and left-sided pleuritic pain. She had been well until 2 months earlier, when she experienced left-sided thoracic pain irradiating to the shoulder. The pain was accompanied by exertional dyspnea (grade II) as well as by a non-productive cough.

Palpitations, night sweats or fever were not reported and her weight remained unchanged during the last months. At the time of admission she did not take any medication whatsoever.The patient was a retired housecleaner and had never smoked. She had a remote history of mettoragies, surgically cured by a hysterectomy, and urinary incontinence due to vesical prolapse. Although she had a family history of cardiac disease, she herself had never suffered previously from cardiac disease.

At the time of admission her temperature was $36.6^{\circ} \mathrm{C}$, pulse 100 beats per minute, and the respiratory rate 30 per minute. Blood pressure was $120 / 80$ $\mathrm{mmHg}$. The oxygen saturation was 91 percent while the patient was at rest and breathing room air. No signs of right or left sided heart failure were present. Cardiovascular auscultation revealed a split second heart sound as well as a systolic ejection murmur in the upper sternal border. The lungs were clear and abdominal examination revealed no abnormalities.

Technical examination: A chest x-ray showed a marked cardiomegaly as well as a slight prominent right hilus and broad mediastinum. Blood chemistry and ECG were within normal limits. Blood gases revealed hypoxemia $(60 \mathrm{mmHg})$ and hypocapnia (30 $\mathrm{mmHg}$ ).

Lung function tests, performed because of the pronounced dyspnea, displayed a restrictive flow pattern with normal lung mechanics and volumes, and a significant reduction in lung diffusion capacity, with a measured $\mathrm{DLCO}_{\text {unc }}$ of $10.21 \mathrm{ml} / \mathrm{min} / \mathrm{mmHg}(46 \%)$ and a DL / VA of $1.96 \mathrm{ml} / \mathrm{min} / \mathrm{mmHg} / \mathrm{L}(33 \%$ of predicted volume).

Based on these findings a ventilation-perfusion scan was performed which revealed a marked decrease in pulmonary perfusion and a slight decrease in ventilation in both lungs, compatible with bilateral pulmonary thrombo-embolism. To asses the hemodynamic effects transthoracic and transesophageal echocardiography were performed. We noticed 2D and Doppler evidence of right ventricular pressure overload. The right chamber appeared dilated and the interventricular septum deviated to the left with an estimated systolic right ventricular pressure of $70 \mathrm{mmHg}$. A large obstructive intracardiac mass was seen in the right ventricular outflow tract, protruding through the pulmonary valve into the main pulmonary artery. 
The presence of this intracardiac mass was confirmed by MRI (Figure $1 \mathrm{~A}, \mathrm{~B})$ and CT angiography, as well as by pulmonary angiographic examination. A mass (maximum diameter of $2.3 \mathrm{~cm}$ and $4.0 \mathrm{~cm}$ long) protruded into the right ventricle through the pulmonary valve. The density of the mass was not compatible with thrombus material.

A biopsy under ultrasonic guidance and a right heart catheterization to assess the hemodynamic repercussions of the mass were not carried out since the risk of embolisation by dislodging material was considered to be too high.

Surgical Resection: Surgery was deemed necessary because her symptoms progressed and the exact origin of the cardiac mass remained uncertain.

After instituting extracorporeal circulation, complete macroscopical resection of the tumor was performed under myocard-protection (Fresinius ${ }^{\circledR}$ ) and moderate hypothermia $\left(32^{\circ} \mathrm{C}\right)$. The tumor measured $5 \mathrm{~cm}$ in diameter and was rooted in the right lateral ventricle wall, directly under the pulmonary valve. There were no postoperative complications and the patient was discharged 1 week after surgery.

Histologic findings: Macroscopic examination of the resected specimen showed a gelatinous, polypoid mass. Routine histologic examination revealed a tumor with a distinct myxoid stroma and densely packed cells with elongated, irregular, enlarged and hyperchromatic nuclei. High mitotic activity was detected (31 mitotic figures per 10 high-power fields in areas of high cellularity) and focal nuclear atypia was present. The tumor border consisted of fibrinoid material.

Immunohistochemical staining was positive for vimentine and desmine (Figure 2 A, B) and negative for cytokeratine and S-100.

On the basis of the microscopic and histological findings, a diagnosis of high-grade spindle cell sarcoma, and more specifically a leiomyosarcoma, was made.

Follow-up and further management: After resection extensive screening was performed, including PET-scan and CT thorax, abdomen and brain which excluded tumor metastasis and other abnormalities. One month after surgery the patient was in good general health, with a significant decline in dyspnea complaints. Right and left cardiac catheterization and a coronary arteriogram showed no irregularities and the lung perfusion-ventilation scan remained unchanged.

A wait-and-see policy was deemed the most favourable approach since evidence for the beneficial effect of chemotherapy remains scarce and a heart transplantation was considered to be too aggressive. The patient was advised to undergo close follow-up.

Seven months following resection, the patient presented with recurrent dyspnea. At that time relapse of the tumor was detected which warranted further palliative measures. 


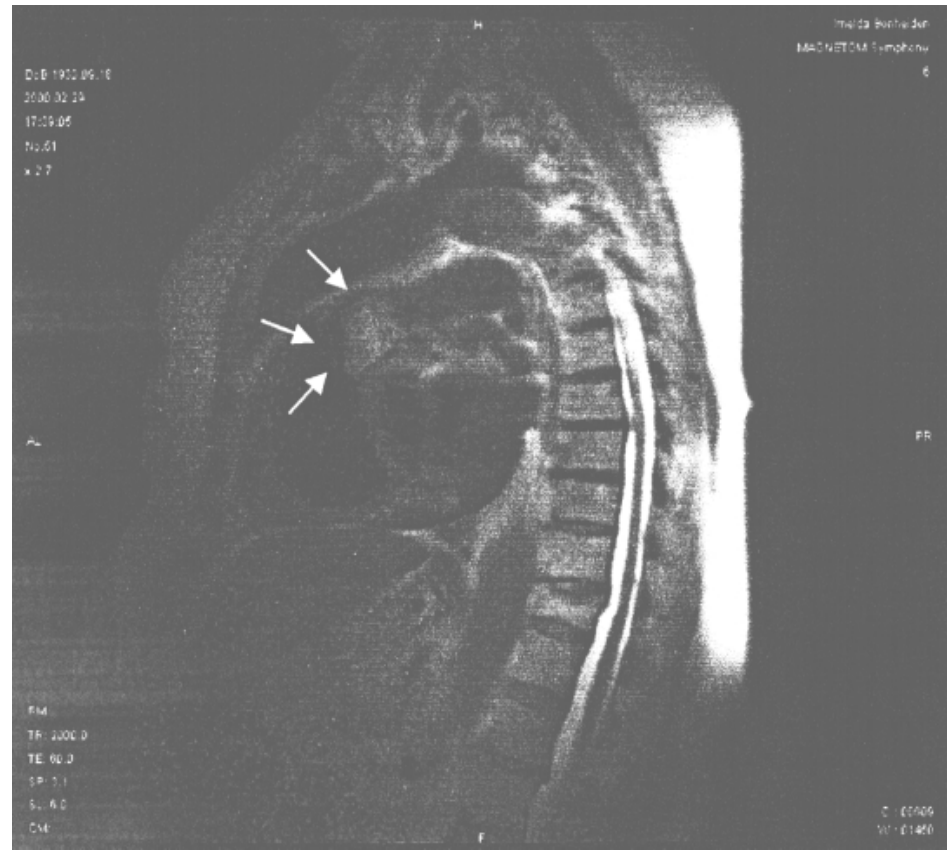

\section{B}

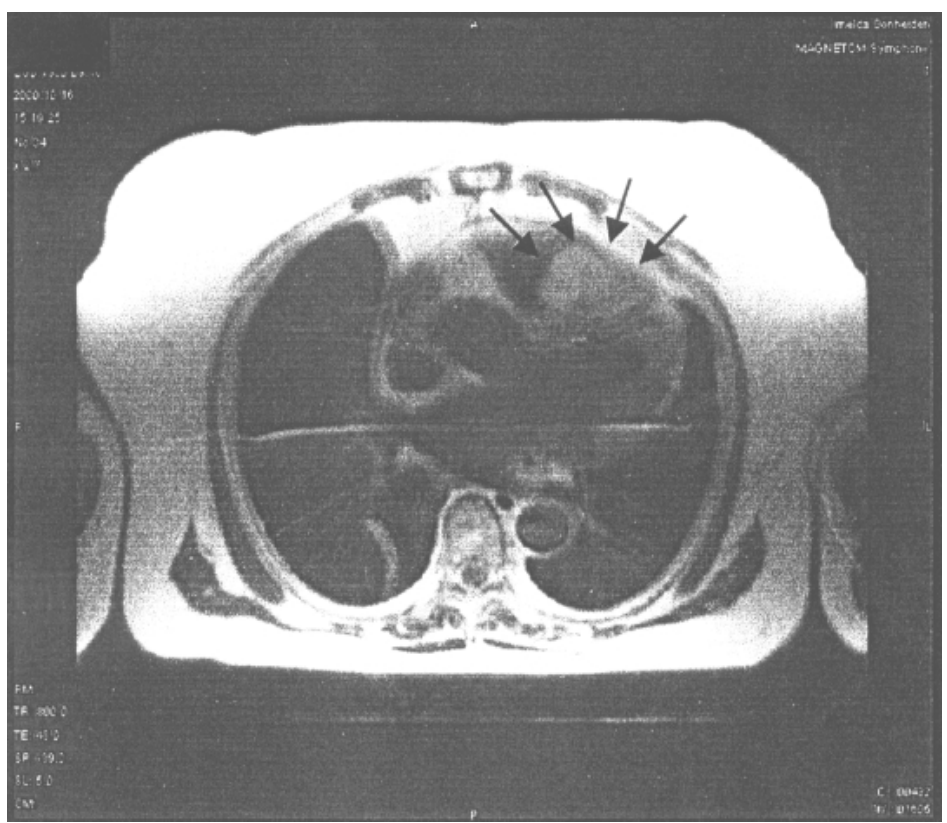

Figure 1A, B. MRI on admission: sagittal planes (1a) and transverse plane (1b) showing the tumor (arrow) in the right ventricle protruding through the pulmonary valve into the pulmonary trunk. Significant enhancement of the mass was noted afrer gadolinium injection. 

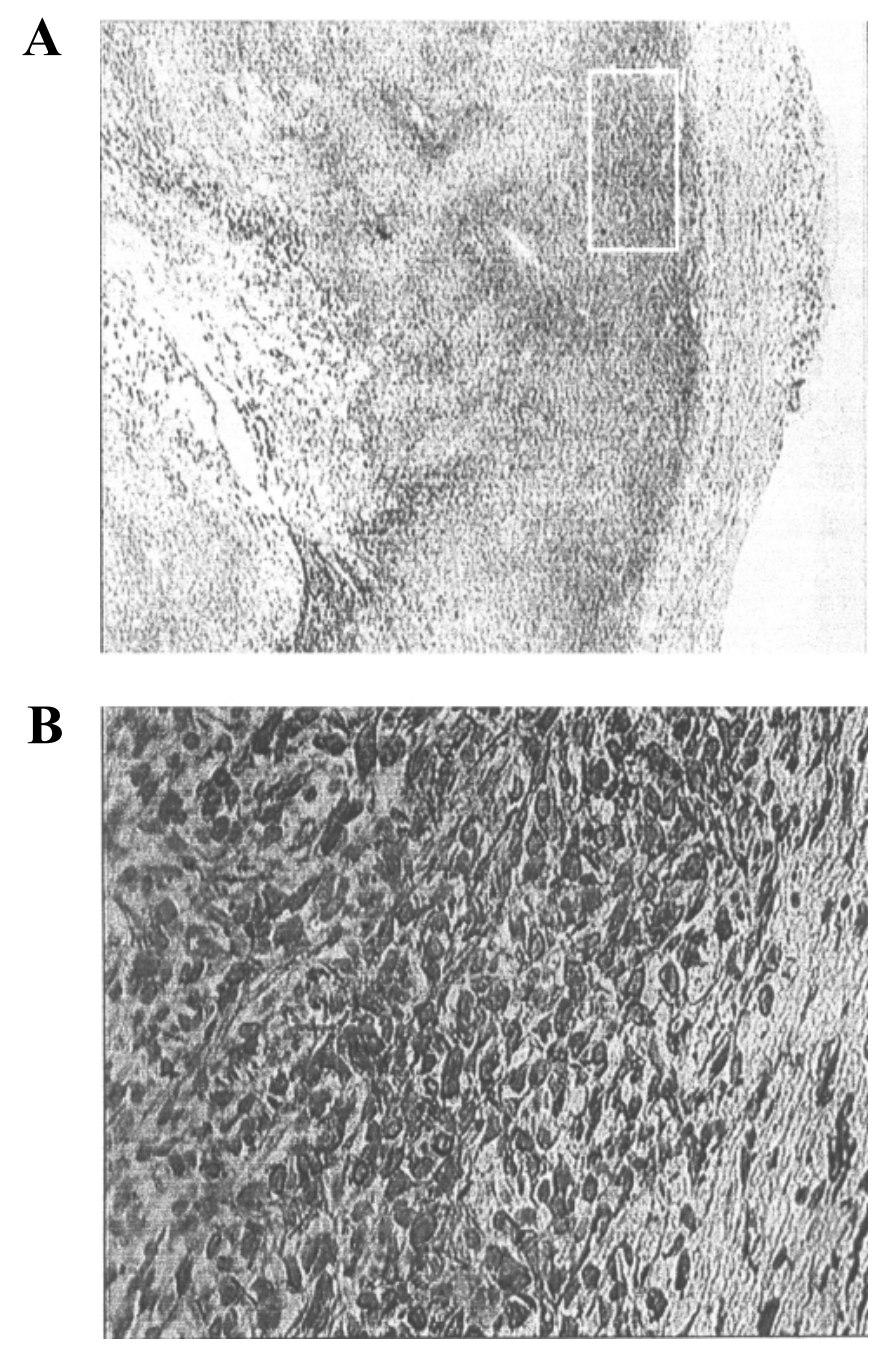

Figure 2A, B. Histological examination (desmine staining): 2a (40x magnification) showing histological characteristics of a leiomyosarcoma: a myxoid stroma, irregular, hyperchromatic nuclei with atypia and high mitotic activity. $2 \mathrm{~b}$ is higher magnification (400x) of boxed area in $2 \mathrm{a}$.

\section{DISCUSSION}

Incidence: Cardiac tumors are rare. They are primary if they originate from the heart and secondary if they metastasize from other malignancies. With an incidence of 0.0017 to $0.28 \%$ in autopsy series, primary tumors of the heart are far less common than metastatic heart tumors. Seventy-five percent ${ }^{1)}$ of all cardiac 
tumors are benign and therefore curable. Almost all malignant cardiac tumors are sarcomas $^{2,4,5)}$ and of these the angiosarcomas ${ }^{4)}$ and rhabdomyosarcomas are the most common form. They tend to be vascular in origin, particularly the angiosarcomas, and are more frequently right-sided ${ }^{5)}$ and in the atrium. ${ }^{2,7,8)}$

Leiomyosarcomas represent an extremely small minority of sarcomas. The US Armed Forces Institute of Pathology Files ${ }^{2}$ have recorded only 1 case among 533 primary cardiac tumors $(0.19 \%)$. Burke, et al ${ }^{5}$ reported that only 4 of 75 sarcomas could histologically be classified as leiomyosarcomas (5\%) whereas 26 (35\%) were angiosarcomas. Although any age-group can be affected, they reported a low mean-age for the four leiomyosarcomas (18 years) and a relatively young age for sarcomas in general (39 years).

Diagnosis: Clinical Presentation: The low incidence, unpredictable course and variable clinical presentation of a leiomyosarcoma of the right ventricle makes the diagnosis a challenging one. Symptoms associated with the presence of a leiomyosarcoma in the right ventricle are to a great extent related to its precise localisation, size and invasive behaviour (Table I). Approximately three quarters of patients with a primary tumor of the pulmonary artery present with dyspnea, and slightly more than half of them have chest pain or a non-productive cough. In many cases the diagnosis is misdiagnosed as pulmonary thrombo embolism, and the correct diagnosis is often made only at the time of surgery. Myocardial, pericardial, intracavitary or valvular localisation provoke right heart failure, and valve stenosis, rhythm alterations, conduction abnormalities, hemopericardium or sudden death have all been reported.9,10,11)

Echocardiography: Transthoracic and transesophageal echocardiography have become a useful, non-invasive tool for the diagnosis of cardiac tumors. Involving no risks, they reveal a high sensitivity in detecting intracardial masses. The size, consistency and movement of the mass and its relation with the surrounding structures can easily be registered and the postoperative course can be efficiently monitored.

In addition, transesophageal echocardiographic guided transvenous biopsy appears to be a safe and valuable technique for obtaining tissue samples for histological diagnosis. ${ }^{12)}$

However, echocardiography has its limitations. ${ }^{13)}$ Lung or pleural disease and abnormal chest configurations lead to poor image quality. A limited amount of sectional anatomy, and inability to adequately assess the pericardium, great vessels and extracardiac structures, limit the diagnostic value of $2 \mathrm{D}$ echocardiography. In addition, poor tissue discrimination and limited resolution of tissue planes lead to underestimation of pathology.

Nevertheless, echocardiography is considered to be an ideal tool for the initial diagnosis of intracardiac masses and is of great value in evaluating the hemo- 
Table

\begin{tabular}{|c|c|c|c|c|}
\hline Author & $\begin{array}{l}\text { Age, sex and } \\
\text { clinical presentation }\end{array}$ & Diagnostic procedures & $\begin{array}{l}\text { Non-cardiac } \\
\text { presentation }\end{array}$ & $\begin{array}{l}\text { Treatment } \\
\text { and survival }\end{array}$ \\
\hline $\begin{array}{l}\text { Kennedy }{ }^{(26)} \\
(1967)\end{array}$ & $\begin{array}{l}57 \text {, female, adenopathy } \\
\text { deterioration of general } \\
\text { condition, acute onset } \\
\text { of dyspnea. }\end{array}$ & $\begin{array}{l}\text { negative angiography } \\
\text { diagnosis on autopsy. }\end{array}$ & $\begin{array}{l}\text { Pulmonary, pleural, } \\
\text { hepatic, pancreatic } \\
\text { metastasis on autopsy. }\end{array}$ & $\begin{array}{l}\text { Radio- and } \\
\text { chemotherapy. } \\
\text { Died } 17 \text { months after } \\
\text { diagnosis of adenopathy. }\end{array}$ \\
\hline $\begin{array}{l}\text { Bearman }^{(9)} \\
(1974)\end{array}$ & $\begin{array}{l}69, \text { female, adenopathy } \\
\text { acute right heart failure }\end{array}$ & $\begin{array}{l}\text { negative angiography } \\
\text { negative echography } \\
\text { diagnosis on autopsy. }\end{array}$ & $\begin{array}{l}\text { Pulmonary, renal, } \\
\text { pancreatic } \\
\text { metastasis on autopsy. }\end{array}$ & $\begin{array}{l}\text { No surgery, died } \\
7 \text { months after } \\
\text { diagnosis of right heart failure }\end{array}$ \\
\hline $\begin{array}{l}\text { Burnett }^{(10)} \\
(1975)\end{array}$ & $\begin{array}{l}60, \text { female, pericardial } \\
\text { effusions causing } \\
\text { tamponade }\end{array}$ & $\begin{array}{l}\text { negative angiography } \\
\text { negative pericard biopsy } \\
\text { diagnosis on autopsy. }\end{array}$ & $\begin{array}{l}\text { Pulmonary, hepatic } \\
\text { metastasis on autopsy. }\end{array}$ & $\begin{array}{l}\text { No surgery, died } \\
\text { several months after } \\
\text { onset of symptoms. }\end{array}$ \\
\hline $\begin{array}{l}\text { Talley }{ }^{(15)} \\
(1986)\end{array}$ & $\begin{array}{l}46 \text {, male, right heart fail- } \\
\text { ure }\end{array}$ & $\begin{array}{l}\text { positive angiography } \\
\text { positive echography. }\end{array}$ & None reported. & $\begin{array}{l}\text { Partial resection, } \\
\text { died } 10 \text { months after } \\
\text { onset of symptoms. }\end{array}$ \\
\hline $\begin{array}{l}\text { Egloff }^{(25)} \\
(1991)\end{array}$ & $\begin{array}{l}27 \text {, male, thoracic pain, } \\
\text { systolic murmur, } \\
\text { cough. }\end{array}$ & $\begin{array}{l}\text { positive echography } \\
\text { positive CT. }\end{array}$ & $\begin{array}{l}\text { Pulmonary, pleural } \\
\text { metastasis on chest } \\
\text { x-ray. }\end{array}$ & $\begin{array}{l}\text { Complete resection. Still alive } \\
>22 \text { months after } \\
\text { onset of symptoms. }\end{array}$ \\
\hline $\begin{array}{l}\text { Panday }{ }^{(18)} \\
(1997)\end{array}$ & $\begin{array}{l}\text { 67, male, progressive } \\
\text { dyspnea, systolic murmur. }\end{array}$ & $\begin{array}{l}\text { positive angiography } \\
\text { positive echography. }\end{array}$ & None found. & $\begin{array}{l}\text { Complete resection. Still alive } \\
>3 \text { years after onset of symp- } \\
\text { toms. }\end{array}$ \\
\hline $\begin{array}{l}\text { Willaert } \\
(2000)\end{array}$ & $\begin{array}{l}70, \text { female, thoracic pain, } \\
\text { progressive dyspnea, } \\
\text { systolic murmur. }\end{array}$ & $\begin{array}{l}\text { positive echography } \\
\text { positive } \mathrm{CT} \text { and MRI } \\
\text { perioperative diagnosis. }\end{array}$ & None found. & $\begin{array}{l}\text { Complete resection. Relapse } 7 \\
\text { months after surgery. } \\
\text { Still alive } 10 \text { months } \\
\text { after onset of symptoms. }\end{array}$ \\
\hline
\end{tabular}

dynamic repercussions. Its limitations however necessitate additional imaging modalities to improve preoperative diagnosis.

$\underline{C T}$ and MRI: $\mathrm{CT}$ and MRI play valuable roles in the diagnosis of intracardiac tumors. ${ }^{13,14)}$ The high quality images and multiple planes provide excellent evaluation of tumor localisation and possible extension into contiguous great vessels. In addition, tissue characterisation can be performed with both techniques. These aspects make CT and MRI useful in preoperative surgical staging and helps in determining the benign or malignant origin of the neoplasm. A valuable aid in the differential diagnosis is the enhancement of sarcomas on MRI after the administration of gadolinium, in contrast to the absence of enhancement of thrombi. Right heart catheterisation and angiography: Right heart catheterisation quantifies the extent of right ventricular hypertension caused by the outflow obstruction, whereas right ventricular angiography allows anatomical demarcation of the mass. However, the risk of volume overload due to the use of contrast media, and 
respiratory distress because of thrombus dislodging following the procedure should not be overlooked. ${ }^{15}$ )

Histopathologic examination and immunohistochemical analysis: A definitive diagnosis requires pathological examination of the tissue, obtained by intravascular percutanous or surgical biopsy. High mitotic activity, cell necrosis, cellular atypia, and characteristics of invasion are associated with malignant neoplasms. Sarcomas tend to infiltrate within the intima and progressively obstruct blood flow, embolize in the pulmonary arteries and invade surrounding lung parenchyma.

Monoclonal antibodies against cytokeratin, smooth muscle actin, desmin, vimentin and myoglobin, leucocyte common antigen, polyclonal antiserum to S100 protein and factor VIII can all help in the histological classification of resected sarcomas. Furthermore, they can exclude a sarcoma when there is any suspicion of a lymphoma. ${ }^{5)}$ Cytokeratin (carcinoma) and S-100 (liposarcoma) immunohistochemical staining are negative for leiomyosarcomas which are characterised by extensive expression for vimentin, desmin, and smooth muscle actin. $^{16)}$

Treatment: When a diagnosis of malignancy is established, surgical intervention is mandatory as the natural progression inevitably leads to irreversible heart failure, metastasis and death. Because cardiac sarcomas are exceptionally rare, data from large randomised trials are not available and therefore an exact treatment remains undetermined. Hence to date there is no consensus on an optimal treatment strategy. Radical surgical intervention seems to be the preferred strategy and offers the best hope for palliation and prolonged survival. Surgery is also indicated to obtain a definitive histological diagnosis and as a debulking procedure, to remove obstructive pulmonary arterial extensions that cause outflow obstruction, in non-resectable masses.

Numerous reports of surgical interventions show that initial operative success can be expected, ${ }^{1,3,17-20)}$ however, long-term survival has not yet been ascertained. Putnam, et al ${ }^{17)}$ reported that patients with complete tumor resection had a significantly higher survival rate (median survival of 24 vs 10 months). A case report by Panday, et al ${ }^{18)}$ describes a patient still free of recurrence after a 3-year follow-up period. Nevertheless, surgical treatment is primarily considered to be a palliative measure.

Although Babatasi, et $a^{21)}$ reported a favourable outcome after heart transplantation for a recurrent leiomyosarcoma of the left atrium, more research is needed to examine the effectiveness of this procedure and its prognostic impact.

The benefits of postoperative chemotherapy and radiotherapy are unknown. Some authors claim a beneficial effect for chemotherapy, ${ }^{19,22,23)}$ whereas others express no effect at all. ${ }^{17,24)}$ 
Survival data: Burke, et $a l^{5)}$ and other authors have found that histological grading correlates with survival. High mitotic activity and necrosis is associated with a poor survival outcome. Right-sided tumors are associated with a worse survival, presumably due to late diagnosis compared to left-sided tumors. The histological type of the sarcoma and the degree of differentiation do not affect the overall prognosis.

The overall prognosis of patients diagnosed with cardiac sarcomas is poor. This is because by the time dyspnea, chest pain and hemorrhagic pleural effusions have appeared and the patient seeks medical attention, the tumor is likely to have embolized extensively to one or both lungs. Complete resection of tumor tissue improves the survival but tumor recurrence and metastasis are frequent and the average survival rate rarely exceeds 1 year. ${ }^{3)}$ As soon as signs of right heart failure develop, the prognosis severely worsens and survival is measured in months. As can be concluded from Table I (adapted from Egloff, et al ${ }^{25}$ ), 5 of the 7 cases of primary leiomyosarcoma in the right ventricle exhibit similar disappointing survival rates.

\section{CONCLUSION}

Right ventricular systolic outflow obstruction is most commonly caused by thromboembolism, congenital disorders such as pulmonary stenosis, or tumors located in the anterior mediastinum. Leiomyosarcomas of the right ventricle extending across the pulmonary valve are an uncommon cause, and are associated with a catastrophic prognosis. Treatment is unsatisfactory, relapse and tumor spread are frequent, and life expectancy is short. Early diagnosis is difficult but enhances the chance for extensive radical surgical resection, thereby prolonging survival rates. More research should be done to assess the optimal management of leiomyosarcomas, the roles of chemotherapy, radiotherapy and heart transplantation, and to optimise diagnostic examinations to aid rapid identification of this rare but terminal disease.

\section{REFERENCES}

1. Silverman NA. Primary cardiac tumors. Ann Surg 1980; 191: 127-38.

2. McAllister HA, Fenoglio JJ. Tumors of the cardiovascular system. In: Atlas of Tumor Pathology, Fascicle 15, series 2. Washington DC: Armed Forces Institute of Pathology 1978.

3. Dein JR, Frist WH, Stinson EB, et al. Primary cardiac neoplasms: Early and late results of surgical treatment in 42 patients. J Thoracic Cardiovasc Surg 1987; 93: 502-11.

4. Tazelaar HD, Locke TJ, McGregor CGA. Pathology of surgically excised primary cardiac tumors. Mayo Clinic Proc 1992; 67: 957-65.

5. Burke AP, Cowan D, Virmani R. Primary sarcomas of the heart. Cancer 1992; 69: 387-95.

6. Glancy DL, Morales JB, Roberts WC. Angiosarcoma of the heart. Am J Cardiol 1968; 21: 413 
7. Miralles B, Bracamonte L, Soncul H, et al. Cardiac tumors: clinical experience and surgical results in 74 patients. Ann Thorac Surg 1991; 52: 886-95.

8. Molina JE, Edwards JE, Ward HB. Primary cardiac tumors: experience at the University of Minnesota. Thorac Cardiovasc Surg 1990; 38: 183-91.

9. Bearman RM. Primary leiomyosarcoma of the heart. Report of a case and review of the literature. Arch Pathol 1974; 20: 125-8.

10. Burnett RA. Primary cardiac leiomyosarcoma with pulmonary metastases: a diagnostic problem. Scott Med J 1975; 20: 125-8.

11. Cherrier F, Cuilliere M. Tumeurs primitives du ventricle droit. A propos de 3 observations. Ann Cardiol Angeiol 1973; 22: 473-81.

12. Lynch M, Clements SD, Shanewise JS, Chen CC, Martin RP. Right-sided cardiac tumors detected by transesophageal echocardiography and its usefulness in differentiating the benign from the malignant ones. Am $\mathrm{J}$ Cardiol 1997; 79:781-4.

13. Chaloupka JC, Fishman EK, Siegelman SS. Use of CT in the evaluation of primary cardiac tumors. Cardiovasc Intervent Radiol 1986; 9: 132-5.

14. Shimojo M, Tsuda N, Kamihata H, et al. Magnetic resonance imaging for cardiovascular masses. J Cardiol 1989; 19: 583-92.

15. Talley JD, Franch RH, Clements SD, Murphy DA, Sewell CW. Primary right ventricular leiomyosarcoma producing outflow tract obstruction. Am Heart J 1986; 112: 1335-8.

16. Pucci A, Gagliardotto P, Papandrea C, et al. An unusual myxoid leiomyosarcoma of the heart. Arch Pathol Lab Med 1996; 120: 583-6.

17. Putnam JB, Jr., Sweeney MS, Colon R, Lanza LA, Frazier OH, Cooley DA. Primary cardiac sarcomas. Ann Thorac Surg 1991; 51: 906-10.

18. Panday VR, Cramer MJ, Elbers HR, de la Riviere AB, Ernst SM, Plokker HW. Primary leiomyosarcoma of the heart presenting as obstruction to the pulmonary trunk. Am Heart J 1997; 133: 465-6.

19. Babatasi G, Massetti M, Agostini D, et al. Leiomyosarcoma of the heart and great vessels. Ann Cardiol Angeiol (Paris) 1998; 47: 451-8.

20. Murphy MC, Sweeney MS, Putnam JB Jr, et al. Surgical treatment of cardiac tumors: A 25-year experience. Ann Thorac Surg 1990; 49: 612-7.

21. Babatasi G, Massetti M, Agostini D, et al. Recurrent left-sided heart leiomyosarcoma: should heart transplantation be legitimate? J Heart Lung Transplant 1998; 17: 1133-8.

22. Pessotto R, Silvestre G, Luciani GB, et al. Primary cardiac leiomyosarcoma: seven-year survival with combined surgical and adjuvant therapy. Int J Cardiol 1997; 60: 91-4.

23. Rhomberg W, Grass M. Angiosarcoma of the right atrium: local control via low radiation doses and razoxane. A case report. Strahlenther Onkol 1999; 175: 102-4.

24. Llombart-Cussac A, Pivot X, Contesso G. Adjuvant chemotherapy for primary cardiac sarcomas: the IGR experience. Br J Cancer 1998; 78 : 1624-8.

25. Egloff P, Le Metayer P, Roques X, De Mascarel A, Baudet E, Warin JF. Leiomyosarcoma of the right ventricle. Report of a case and review of the literature. Arch Mal Coeur Vaiss 1991; 84: 1483-7.

26. Kennedy FB. Primary leiomyosarcoma of the heart. Cancer 1967; 20: 2008-12. 
